\title{
OUTLAWS ON THE JADE ISLAND: RUNAWAY VIETNAMESE MIGRANT WORKERS IN TAIWAN
}

\author{
$\mathrm{Vu}$ Le Toan Khoa \\ Department of Southeast Asian Studies \\ National Chi Nan University, Taiwan \\ (s102108906@mail1.ncnu.edu.tw, toankhoahcm@yahoo.com) \\ DOI: https://doi.org/10.22452/jati.vol24no1.7
}

\begin{abstract}
The phenomenon of 'runaway' migrant contract workers in Taiwan has attracted the attention of both the Taiwanese and Vietnamese governments. According to the National Immigration Agency in Taiwan, by 31 October 2017, the total number of runaway foreign workers was 52,891. Of these, Vietnamese workers were the largest subgroup, at 25,626 people. This research draws on data from indepth interviews with 49 'runaway' Vietnamese migrant workers in Taiwan. This research study not only explores the factors that force some Vietnamese migrant workers to give up their legal status and become outlaws in Taiwan, but it also provides a detailed understanding of the daily lives and working conditions of illegal Vietnamese workers. This research study reveals that migrant social networks play an important role in the lives of Vietnamese workers, offering a vital source of material and psychological support. Moreover, the research also shows how huge debt and guest-worker policies force Vietnamese migrant workers to run away.
\end{abstract}

Keywords: Vietnam, foreign worker, illegal working, runaway migrant workers/escaping migrant workers, social network, Taiwan

\section{Introduction}

Since the 1960s, the blossoming economy in Taiwan has promoted industrialisation of the island. Then, in the 1970s, as the economy continued to prosper and the population involved in agriculture began to decrease, citizens' education levels and basic living standards started to grow. These factors led to the majority of Taiwanese young people losing interest in what is perceived as low-prestige, "dirty" industrial labour. The resultant shortage of low-skilled labour greatly impacted on the economic growth. By the late 1980s, the number 
of irregular workers in Taiwan had increased alongside employers' demands for low-cost foreign workers. In response to the situation, Taiwan's Executive Yuan then approved a plan called the "Responsive Measures of 14 Major Construction Manpower Needs", and the term waiji laogong (foreign workers) was born in October 1989. For the last three decades, waiji laogong have been performing work classified as "3D" (dirty, dangerous, and difficult) in addition to serving as domestic workers in private homes. These foreign workers are also called migrant workers.

According to statistics from the Ministry of Labour (2016), the number of foreign workers in Taiwan had increased to 556,412 by the end of January 2015, and the number of Vietnamese workers alone was 152,000, making it the second highest nationality amongst the total population of foreign workers in Taiwan at that time.

At the turn of the century, Taiwan began to experience some problems importing foreign labour. The most common problem highlighted in the news media was that of foreign workers escaping from their contracted working positions. According to the Department of Immigration in Taiwan, by 31 October 2015, the total number of foreign workers who escaped from their position was 51,464 people. Vietnamese workers made up over half of this group, with 25,210 people, while Indonesian workers were second at 22,820, and Philippine workers were third at 2,565 (Department of Immigration in Taiwan, 2015).

Because of the high rate at which Vietnamese workers abscond from their jobs, the Taiwanese government imposed a ban on the hiring of Vietnamese fishermen in May 2004 and on caregivers and domestic workers in 2005. Vietnamese workers were still allowed to work in Taiwan in other fields, such as the manufacturing sector. Besides this, the Vietnamese government also issued Decree No. 95/2013/NĐ-CP, which was effected in October 2013 and imposes a heavy fine of between 80 million and 100 million dong (US\$3,500-4,800) on Vietnamese workers who quit their job without permission and illegally stay in foreign countries. Despite this measure, the number of runaway Vietnamese workers has continued to rise.

A lack of legal protection renders the vast majority of runaway migrant workers vulnerable in many aspects, such as exploitation, deportation, and inadequate healthcare. Take, for example, the case of Nguyen Quoc Phi, a runaway migrant worker from Vietnam, who, as an alleged car thief, was killed after being shot nine times by police in north-western Taiwan on 31 August 2017. The case immediately sparked a debate about the treatment of migrant workers in Taiwan (Sui, 2017). Vietnamese migrant workers staged a protest outside Taiwan's National Police Agency headquarters in Taipei to demand the release of 
the surveillance video footage of the shooting. However, the police have yet to release the video footage.

This research study explores the economic burdens of Vietnamese workers and the structural vulnerabilities of Taiwan's migrant worker policies that play a role in Vietnamese workers running away from their current employers to work illegally. In addition, this study discusses working experiences, survival strategies, and job seeking, as well as the role of social networks, economic duties, and the daily trials of Vietnamese workers who are on the run.

\section{Literature Review}

According to previous research, some of the reasons why foreign workers ran away can be summarised as follows: First, some foreign brides or runaway migrant workers in Taiwan contact legitimate foreign workers, who they then seduce into illegal work, sometimes even tricking them into the sex industry (Chiou, 2008). Second, foreign workers do not want to return to their country after their contract ends, because they are afraid they cannot find jobs in their own countries that pay as well as their job in Taiwan (C. Y. Wu, 2007; Chiou, 2008). Third, foreign workers may have difficulties adapting to the work environment back home and/or other personal factors after working in Taiwan for a while (H. L. Wu, 2000). Fourth, foreign workers have to face significant economic pressure because they are required to pay an expensive fee to their agency before they can come work in Taiwan (Sheu, 2000; Wang, 2004; Wang \& Bélanger, 2007, 2011). Fifth, foreign workers are mistreated and threatened by their employers for several years and/or exploited by their agency (B. H. Lin, 2004; H. F. Lin, 2007).

The institutional theory of migration is also relevant for examining the migrant flow and process we are interested in learning about. Some researchers indicate that Asian governments play the greatest role in the management of migration flows, from handling recruitment, training potential migrants, placement, handling remittance, and promoting their workers to receiving countries (Hugo, 1995; Lan, 2006; Castles \& Miller, 2009; Rodriguez, 2010). However, Lan (2006) also points out that Asian migration regimes have strict regulations that are enforced by hosting governments. These migrants accept short-term employment, with specific job contracts, and have to return home upon completion of their contract period (Sarker, 2016). As a result, many migrant workers encounter risks and, in particular, they frequently report sexual harassment and other forms of abuse from their employers, including threats of deportation and slave-like treatment (Chang, 2000). 
In view of this, certain questions arise: how do runaway foreign workers find a job after escaping from their previous employer even when they are not familiar with the environment and the language? What do they do to make a living? Who is helping them all this while? This is when social networks are extremely important to migrant workers. Social networks not only provide important resources of social capital for migrants, but they also reduce the risks and costs of migration (Choldin, 1973; Elrick \& Lewandowska, 2008). Massey (1988) defines social networks as "sets of interpersonal ties that link migrants, former migrants, and non-migrants to one another through relations of kinship, friendship, and shared community origin". Boyd (1989) also points out that friends and relatives may provide migrants with useful resources, such as food, shelter, job opportunities and contacts, information on social services, and emotional support.

Moreover, Massey, Alarcón, Durand, and González (1987) appear to have been the first to describe migrant networks as a source of social capital. Since then, numerous migration scholarships have begun to utilise the concept of social capital as a crucial tool for understanding how networks affect migration. Bourdieu and Wacquant (1992) use the following definition: "Social capital is the sum of resources, actual or virtual, that accrue to an individual or group by virtue of possessing a durable network of more or less institutionalised relationships of mutual acquaintance and recognition" while Putnam (2007) defines social capital as "social networks and the associated norms of reciprocity and trustworthiness". He identifies two dimensions of social capital: bonding "ties to people who are like me in some important way"; for example, people from the same country or language group, while also bridging "ties to people who are unlike me in some important way". However, as Putnam (1995) indicates, the benefits of social capital are not always positive; they can also be negative and destructive. Hoang (2016) suggests that social capital and social networks are deeply embedded in the inequalities and vulnerabilities engendered by restrictive migration regimes.

Furthermore, Putnam's (2007) findings suggest that not all networks have exactly the same effects, and "the more ethnically diverse the people we live around, the less we trust them". Not only do we trust others less, but, according to Putnam, we also barely trust others within our own group. Similarly, Williams (2006) has noted that one's wider ethnic community may be perceived in negative terms as a source of competition, pressure or even danger. Hence, trust plays a critical but variable role in social networks. 
In this research study, I take this topic a step further by focusing on the migrant network of Vietnamese migrant workers as well as the highly restrictive migration regime in Taiwan.

\section{Methodology}

This research study conducted a series of in-depth interviews with participating migrant workers. I implemented 49 in-depth interviews with runaway Vietnamese migrant workers in 2011, 2012, and 2017 ( $\mathrm{n}$ male $=35 ; \mathrm{n}$ female $=14$ ). The interviews were carried out in Taipei City, New Taipei City, Taichung, Sanxia, Nantou, and Puli. I conducted all the interviews in Vietnamese, audio-recorded them, and later transcribed and coded them. All of the interviewees' identities are kept confidential through the use of pseudonyms. The duration of the interviews varied from thirty minutes to ninety minutes. The interviewees, aged 20-43, were from northern and central Vietnam. Most of them were still single and worked in factories. They had been living in Taiwan between one and ten years. I also conducted extensive observation at migrant settings, such as Vietnamese restaurants, karaoke locations, discotheques, railway stations and parks.

In addition, because I am also Vietnamese, I was able to communicate with the store owners and workers in Vietnamese and befriend them more easily. This really helped in building a close relationship with them. I had the opportunity to live and work with them and gain their trust and consent through long-term interaction. I also conducted interviews with five illegal employers and three brokers.

Most research into this topic has focused on foreign workers who have been apprehended and have been waiting for deportation back to their home country. In contrast, this research focuses on Vietnamese workers who have run away and have yet to be captured.

\section{Vulnerability and Risks of Running Away}

Why do Vietnamese migrant workers run away? Firstly, in order to work abroad, migrant workers have to pay job placement fees that vary across countries of origin and destination. In Vietnam, all potential migrant workers first have to pay pre-departure costs, which include fees for recruitment, training, intermediaries, visas, plane tickets and various other contingencies. In my research, all the interviewees indicated that they had to pay pre-departure costs, which ranged from US\$5,700 up to US\$9,000. Then, once in Taiwan, according to Taiwan migrant labour policy, migrant workers also have to pay income tax, physical examination fees, intermediary fees, residence application 
fees, boarding fees, and insurance, all of which are deducted directly from their salaries.

Vietnamese migrant workers come from poor rural areas in Vietnam. In order to finance their migration, they have to borrow money from different sources at high interest rates (between $1 \%$ and $2 \%$ per month), and some of them even mortgage their property to borrow money from banks, relatives or loan sharks. Because of the huge debt accrued before leaving Vietnam, migrant workers face constant salary deductions in the form of so-called "intermediary fees" throughout the course of their careers. Debt is an important part of migrant worker life, as is the case of Mai, who came to Taiwan in 2012 and then ran away in 2014. Mai demonstrates vividly:

My family had to mortgage land to borrow US\$7,500 from the bank to pay the fees. I had to work over-time to repay the debts. Sometimes, I had no time to take care of myself. It is really terrible. (Mai, 25, female)

To add to the woes the migrants face in getting to the island, Taiwan continues to utilise the "guest worker scheme", according to which these migrant workers are regulated very strictly in terms of work terms, residence, and changing employers. According to Article 52 of the Act promulgated on 13 May 2003, migrant workers can renew their contract up to a maximum total of twelve years by leaving Taiwan for at least one day after each three-year period. Many studies indicate that migrant workers have to pay contract renewal fees ranging from NT $\$ 30,000$ to NT $\$ 40,000$. In other words, they are not "free migrant workers"; they are not able to choose employers, work, or their residence. As a result, the scheme allows employers to change and replace foreign workers with a new group of workers from overseas when a contract is finished. Besides this, according to Article 52 of the Act effected on 5 November 2016, migrant workers do not need to leave Taiwan after reaching the maximum permitted stay period before returning to Taiwan to continue working. However, some Vietnamese migrant workers informed me that they had to leave Taiwan before returning to continue working because they are forced to by intermediary companies and employers.

Employers can hire foreign workers for a short term and then replace them with a new set of workers every three years, and they collect higher fees from new workers as a bonus. Some of the brokers I interviewed revealed that many intermediary companies have to pay employers fees in order to get orders. The average amount of this "kickback" fee is NT\$30,000 per worker, yet it can be as high as NT $\$ 100,000$. Of course, these kickbacks are paid by migrant workers 
through intermediary fees. Migrant workers are victims of loan sharks on one side of the South China Sea and biased policies on the other.

Under the guest worker scheme, migrant workers may not freely change employers. They are bound to and dependent upon their employer. Many Taiwanese employers discriminate against and abuse migrant workers by placing them in poor working and living conditions, and then threaten to deport or retain employees if they resist. As is the case of a fire in a solar window film factory in Taoyuan's Lujhu District that killed six Vietnamese migrant workers; the Taiwanese office found that Sican Company, which owned the factory, has a record for non-compliance with municipal labour standards (Chung, 2017). During the interviews, many runaway Vietnamese workers explained that they had to work in hazardous and toxic environments, and they were disrespected and discriminated by their employers.

Finally, as mentioned earlier, my primary research was conducted in 2011 and 2012 when the global economic downturn had deep-reaching negative effects on migrant workers in Taiwan. Some Taiwan-based companies cut production plans. Hence, both local and migrant workers were facing unemployment. Many migrant workers were forced by their brokers and employers to sign resignation papers or to agree to a "no work, no pay" policy or even to take unpaid leave. Some interviewees reported that their companies implemented a "three days work, one day off" policy in which their incomes were barely sufficient to cover their living costs, while still dealing with the threat of being laid off. Many of them faced periods without work lasting three to six months at a time. Hoa describes how her company was affected by the global economic crisis:

My company did not receive any production orders. Many of my Vietnamese colleagues were laid off after two or three months at their job. Although our wages were reduced, we still had to pay intermediary fees. I could not send home any money for four months. So, I had to run away to survive. (Hoa, 24, female)

This was also true for Thanh, a 30-year-old male worker who borrowed US\$5,700 from his relatives to pay the placement fee to work in Taiwan in 2006 and then ran away in 2009. He explains his situation:

At that time, my company didn't need workers to work over-time. After paying placement fees and other fees, I earned around US $\$ 2,500$ for 
nearly three years of work. I think it is not a worthwhile job. (Thanh, 30, male)

Overall, Taiwan's guest worker scheme initially views these foreign migrant workers as human resources to ensure the government's economic goals are achieved. Foreign migrant workers are thereby deprived of basic labour rights that are granted to Taiwanese workers, as these migrants are not expected to become members of Taiwan society. The scheme does not let migrant workers "die", but it does let them "move". Hence, with huge debts resulting from exorbitant intermediary fees, the risk of being dismissed at any time, and being unable to switch employers, migrant workers have essentially been "forced" by the guest worker scheme to become irregular workers. The research also suggests that the more migrant workers' debts increase, the more they tend to run away.

\section{Vietnamese Migrant Networks in Taiwan}

Research shows that Vietnamese runaway workers depend heavily on co-ethnic networks, or bonding social capital (i.e. strong ties), and for advice and information about jobs. Firstly, most Vietnamese migrant workers in Taiwan come from northern and central Vietnam; are deeply influenced by Daoism, Buddhism and Confucianism; and emphasise the principals of collectivism, nhanqua (the rule of causality), benevolence, and nhan nghia (righteousness). Pham (2005) indicates that this particular social setting encourages Vietnamese to feel responsible for other members of the wider society, understanding the individual's life as being in a natural state of connection with others in an integrated organic body. So, when Vietnamese migrant workers arrive to work in Taiwan, they create communities and develop a "culture of Vietnamese migration". They set up hoi dong huong (associations of fellow-countrymen) that include both documented and undocumented Vietnamese workers. Tight networks of co-ethnics can lead members to exchange information about jobs and life and even sometimes pool together funds to help fellow countrymen in tight situations.

These charity activities draw together group members and strengthen the existent bonds of fraternity. Once Vietnamese workers want to run away, they will ask Vietnamese friends to help enquire about available illegal work opportunities. Only after these friends report that they have found such work do the migrant workers take the next step and actually run away. This is exemplified by the experience of twenty-five-year-old Suong, who has been on the run for over five years: 
Jobs play an important role in your decision to run away or not. I left the company once my friend told me that his boss agreed to adopt me. If you cannot get a job, you have to surrender and go back home.

Due to their "illegal" status, some interviewees revealed that they would sometimes ask Vietnamese documented workers to lend them legal documents to help in renting houses or remitting money. Even more so, many interviewees also reported that to avoid being arrested by the police, they would ask their documented friends to provide their basic information (name, date of birth, entry time, residence certificate number, etc.) as a cover to hide their illegal status. If these runaway workers were ever stopped by the police on the street, they would provide this false information and, thereby, might have a chance to escape. Tai, a migrant worker who has been on the run for five years, once used his brother-in-law's legal documents to evade the police:

One night, my friends and I were going home when we were stopped by the police for a random document check. I used documents borrowed from my brother-in-law to show the police. Then, when the police weren't paying attention to me, I ran like the wind.

By giving up their legal status, these runaway workers also forfeit access to the national health care system. In the event of a health issue, Vietnamese runaway workers must either resort to a trip to the pharmacy to buy medicine or borrow a health insurance card from a documented friend. "If I have a little cold," explains Xuan, a 25-year-old who had been on the run for two years at the time, "I would go to pharmacies to buy medicine. If I got a serious cold, I would borrow a friend's health insurance card to see the doctor."

Secondly, Vietnamese runaway workers not only get help from fellow Vietnamese workers, as they also get help from Vietnamese spouses. Many Vietnamese workers reported that they have relatives (sisters, cousins, etc.) living in Taiwan who are married to Taiwanese people, and that they could get help from these relatives should they find it necessary. As Portes (1995) indicates, familial migrant networks not only provide practical support in the form of accommodation and employment, but also provide emotional support. Family migrant networks are also a very important means of acquiring high-quality information to reduce the risks associated with migration. Vietnamese spouses help their relatives expand their social networks in Taiwan, overcome difficulties at work, and, eventually, run away. 
Thirdly, workers also become acquainted with Vietnamese spouses outside their kin group at the many Vietnamese snack bars located throughout Taiwan. Living in a foreign country and sharing the same language, cultural background, and work experiences, it is easy for them to start up informal friendships. Subsequently, many runaway Vietnamese workers even fall in love with already married Vietnamese people. However, this love is often unstable since one of them is an illegal resident. This is exemplified by the story of Hung, who ran away in 2009. In an interview, Hung shared that when he had free time, he would occasionally go to Vietnamese snack bars to dine and relax. In one Vietnamese snack bar, he met Thuong (female). Thuong was a 30-year-old widow who had been married, without children, to a Taiwanese man. When Hung encountered difficulties, Thuong would help him find jobs. Later, because of their matching personalities and perhaps loneliness, they fell in love. Together they helped many runaway Vietnamese workers find jobs. Sadly, all good things must come to an end though, for Hung was eventually caught by police while on his way home from work and then deported, ending their romantic relationship. Hung's story clearly illustrates high levels of bonding within ethnic networks, as he received emotional and practical support from compatriots.

\section{Trust and Rivalry}

As mentioned above, trustworthiness and norms of reciprocity are key elements of social networks. Trust is variable and being able to trust someone takes time. The risk of being betrayed or even reported to the police leads many undocumented workers to cut contact with friends. Ryan, Sales, Tilki, and Siara's (2008) research suggests that migrants have complex relationships with in the wider "ethnic community" that may involve different layers of trust. Therefore, migrants need to balance their distrust with on-going reliance upon co-ethnics. In addition, Hoang's (2015) research on Vietnamese migrant networks in Taiwan indicates that many Vietnamese women deliberately kept a distance from their compatriots, especially those from the same village.

In my research, many interviewees informed me that they knew of many cases of betrayal, rivalry, and competition between Vietnamese migrant workers. Despite this, they tend to help each other, as well as foster and consolidate friendship networks. Trung described:

We know there is much competition between Vietnamese groups, such as they fight at the workplace or they notify the police to arrest other compatriots. However, we still have to depend on co-ethnics and help each other. (Trung, 35, male) 
Besides this, according to Moore's (1990) research, women's networks are typically smaller and more homogeneous than those of men. This is in contrast to runaway Vietnamese female workers, who have more freedom in social activities or finding jobs. According to the statistics of Taiwan's National Immigration Agency, as of 12 December 2016, there were 95,269 Vietnamese spouses living in Taiwan, so runaway Vietnamese female workers can easily blend into the Vietnamese spouse community. Therefore, it helps them avoid the attention of the police and local citizens. This is exemplified by Tham, who ran away nearly two years ago. After running away, she moved to the small city of Puli to live and work. On an evening in March 2012, I went to an elementary school in Puli to interview Vietnamese spouses. I met her and other Vietnamese spouses in a Chinese class offered by the government for new immigrants. If I had not known her before, I would have thought she was one of the Vietnamese spouses who had just arrived in Taiwan. After finishing class, she explained:

After running away, I think of my current life as the same as Taiwanese people and Vietnamese spouses: work, cook, eat and sleep. It's nothing like the time I worked in the factory. The factory's regulations were very strict; Ihad to ask the supervisors before I did anything. I am free now, so I can freely change jobs if I like. I know many Vietnamese spouses who often help me. I sometimes go to work or go to class with them. (Tham, 30, female)

A similar case can be seen with Van, a 23-year-old female worker who came to Taiwan in 2012 and then ran away in 2014. I met her in a small restaurant when I bought lunch in May 2017. At that time, we did not know each other, but when I heard her speak in Vietnamese, I took the initiative to say "hello". She said "hi" to me again, and then told me that she came from Ca Mau (a province in southern Vietnam) and married a Taiwanese man 10 years ago. This surprised me, since she speaks with a Central Vietnamese accent, which is quite different from a Southern Vietnamese accent. I assumed she may have been hiding her status, so I just exchanged information with her then left. After keeping in touch with her for a long time and gaining her trust, she revealed that she was, in fact, a runaway worker. She describes her living experiences in Taiwan:

I have to be careful; many friends were caught by the police because they were reported by compatriots. Only my boss and some close friends 
know I am a runaway worker. There are so many Vietnamese spouses here, so others think I am a Vietnamese spouse, too. You don't need to tell them much. (Van, 23, female)

\section{The Relationship between Vietnamese Runaway Workers and Their Employers}

As mentioned above, Vietnamese runaway workers depend heavily on co-ethnic networks to find jobs. After getting a job, they have to depend on Taiwanese (mostly illegal) employers during their runaway existence. To runaway Vietnamese workers, employment is a key to survival. They only had the courage to run away because they had already found jobs before they were ready to run away. However, undocumented workers often face injustices on the job. As Bloch (2010) indicates, the lack of power can leave undocumented migrants with the lowest paying jobs, working long hours, often isolated, and without any opportunities to improve their situation. This is exemplified by the experiences of Cong:

As you know, I am a runaway migrant worker, so my former bosses asked me to work more hours and paid less money. I sometimes had to work 10 hours a day. I could not say anything, because I need work and money. (Cong, 35, male)

However, most interviewees informed me that although sometimes they were discriminated by their employers, they had to heavily depend on their employers' workload and assistance. If certain illegal employers cannot provide any jobs for runaway workers, they would then introduce them to other illegal employers. Once they had job opportunities, they would contact these runaway workers to come back and work for them, as Tra describes:

After running away, we all want to earn more money to pay off our debts and support our families. If my boss cannot provide jobs for us, he will introduce us to other employers, or we can go out to find another job by ourselves. (Tra, 20, female)

When Taiwanese employers need to recruit runaway Vietnamese workers, they can ask Vietnamese spouses or other runaway workers to introduce them. At that time, Vietnamese spouses and runaway workers can recommend their friends to the employers. Furthermore, research shows that the interdependent relationship between runaway Vietnamese workers and illegal 
Taiwanese employers gave both parties a lot of mutual benefits, such as runaway workers gaining higher wages compared to those with contracted jobs; illegal Taiwanese employers also earn more due to breaking the statutory rights of employees, such as minimum wage and health and safety provisions.

Many illegal employers not only provide job opportunities for runaway workers but also offer shelter or even live together with other runaway workers. These illegal employers often rent rooms from their friends, and many landlords know about the status of their tenants (i.e. runaway foreign workers), but these landlords do not embarrass their illegal employer friends nor expose them to the police. In order to conveniently escape from the attention of the police, illegal employers also drive their workers to and from work every day and provide three meals per day, as Trung and Dung describe in their situation:

My boss provides a room for us to live together. My boss informed us that it is more secure for us, because the landlord is his friend. The boss picks us up to go to work and return home every day. (Trung, 35, male)

We live with our boss. He picks us up to go to work and takes us home every day. (Dung, 21, male)

Similarly, Kiet, a 29-year-old man who ran away in 2007, changed jobs several times. Later, through the help of a friend, he got a job at a construction site. In the beginning, his daily wage was NT $\$ 900$ and then rose up to NT $\$ 1,800$. He lived with his boss, who also adopted many runaway Vietnamese workers. After getting off from work, he was responsible for cooking, but sometimes, if they worked until very late, the boss would buy meals for them. The boss would occasionally take them to go sing in a karaoke bar or eat out in a restaurant. In his mind, the boss is a good person because he runs around finding jobs for them so that they have the opportunity to make more money:

The boss knows we need to earn money to help our families and we have to save money for the future, so he runs around finding jobs for us. Even though we know the boss makes money from our sweat and blood, we still depend on each other and would help each other out of a difficult situation. (Kiet, 29, male)

One of the interviewees who had the deepest impression on me was Phuong. He came to Taiwan in 2007 and worked in a board printing company. After working for a while, the economy went through a slowdown and the 
company could not afford to employ him. In 2009, he finally decided to give up legitimate work and took up the illegal life in Taiwan.

After running away, he changed jobs many times, finally following a small contractor who provided him with daily work at various job sites. His daily wage was NT $\$ 1,800$, and the boss provided accommodation, three meals a day and daily transportation to and from work. Sometimes, the boss even helped him remit money back to Vietnam. In November 2011, he was arrested and deported by the police because someone had reported him. However, he was back in Taiwan again by 2012. This surprised me, because according to Taiwanese labour law, a foreign worker, who broke the law and was deported, cannot apply for jobs in Taiwan for five years. He explained:

I used my brother's information, and then my cousin helped me get a new identity card which cost me two hundred US dollars. After getting a new ID card, I spent two hundred US dollars to make a new passport, and then found a new agency to apply for jobs in Taiwan. When I arrived at Taoyuan Airport, my boss met me, drove me out of the airport, and took me back to his home. My current daily wage is NT\$1,800, and I hope to work in Taiwan as long as possible to keep earning more money. (Phuong, 27, male)

As mentioned above, these Taiwanese employers know that hiring runaway workers is illegal and they can be fined; so why do they take the risk? Why are these Taiwanese illegal employers willing to hire runaway foreign workers? Why are they not afraid of being arrested by the police? In order to further understand their thoughts, I had the chance to interview many illegal Taiwanese employers. Mr. O is an illegal Taiwanese employer employing 10 Vietnamese runaway workers. I asked him why he uses illegal workers. He explained:

Taiwanese young people do not want to do 3D jobs, now! Taiwanese young people are choosy, and middle-aged people cannot do these jobs because this work is too dangerous and requires physical strength. Since I can't find Taiwanese people to do these jobs, I have to hire these illegal workers. We all help each other. They need work to make money and I need employees. The more I earn this month, the more they will earn. We rely on each other to survive. Without these workers, our businesses would be hit hard. $(\mathrm{O}, 57$, illegal employer) 
Regarding the fear of being fined by the police, he had this to say:

No, I am not afraid anymore. I told them that if you were caught by the police, you could not report me. If you reported me, other illegal workers would be deported also because the police would come and arrest all of us. If no one from outside reports the runaway foreign workers to the police, I am all good because I have a good relationship with the people in the construction sites, and they would never rat me out. Besides, I would not employ a lot of runaway foreign workers at one site. I mix my workers with Taiwanese and Vietnamese, so people from the outside will not notice anything fishy going on. $(\mathrm{O}, 57$, illegal employer $)$

Likewise, Mr. P, who is employing illegal workers, explained the following:

These runaway foreign workers work very hard, because they need to earn money to survive. They are unlike the choosy Taiwanese workers. If Taiwanese workers feel unhappy, they will stop working and go home. Taiwanese workers want to leave at 5:00 p.m. Vietnamese runaway workers will only go home once they finish the work that I had laid out for them. They sometimes work until seven or eight o'clock in the evening. Vietnamese runaway workers' work ethic is much better. $(\mathrm{P}, 48$, illegal employer)

As mentioned above, perhaps "supply and demand rules", "obedient and hard-working" runaway workers and "Taiwanese young people are choosy" prompted some employers to ignore the risk of hiring runaway foreign workers, as there are many runaway foreign workers desperately seeking jobs. If these employers would not hire and help runaway foreign workers, would these "runaway foreign workers" be able to survive in Taiwan? And, if there was no cheap labour from runaway foreign workers, would these employers' businesses run smoothly? Runaway foreign workers want to work, and employers need the workers in order for their businesses to earn a profit. These factors make them stick together, like the Chinese saying, "fish help water, water help fish". Both sides need to build trust to live together; one side needs to work hard and cannot report hisher illegal employer while the other side must pay enough of a salary to runaway workers, which includes these runaway workers potentially being caught by the police. They rely on each other to survive. This might explain the main reason why illegal employers hire runaway foreign workers. 


\section{Daily Life of Runaway Vietnamese Migrant Workers}

Life is not so easy for those living in the shadows in Taiwan. They have to live in a climate of fear, feeling uncomfortable and guilt, and sometimes suffering from psychological problems. Kohli (2006) indicates that the fear of being discovered as having an "illegal" status forces migrants into a habit of having secrets. This also occurs with runaway Vietnamese workers, who always choose safe places for their social activities because of the fear of being caught by the police. As a result, after work or during weekends, they just stay home playing video games, surf the Internet, talk on the phone or have parties in their room. They rarely go out to pubs or nightclubs, especially during the times of police crackdowns. In the following quotes, Nam, Tuan, and Binh, describe their situations:

In the first days of being a runaway, I thought a lot of things, so I couldn't eat and sleep well. I lost $8 \mathrm{~kg}$ of weight. It was really a hard time. (Nam, 41, male)

I'm a runaway worker. For my safety, I don't go out as much. My thoughts are if I go out, the police could catch me and have me deported. My friends were caught by the police while they were in a nightclub. This is a huge kind of psychological pressure. (Tuan, 26, male)

After becoming a runaway, I cannot freely go out in the evening. I often stay in my room after work and use my phone to contact my family. (Binh, 25, male)

After running away, most of them do blue-collar jobs, such as working at construction sites or farming in the mountains. To them, although the working hours tend to be longer, these jobs are well paid and allow mobility. Besides this, they often move from employer to employer when they cannot find a stable job. They also often change phone numbers because they want to avoid the attention of the police. Phuong, Tram, and Vui offer three examples:

Although my current job is hard, the salary is good, about NT $\$ 1,800$ per day, working around 20-25 days per month. My boss is a good person. He provides meals, boarding, and picks us up to go to work and come home. (Phuong, 27, male)

You can find jobs quicker in construction and farming over here. If you have experience in construction or farming, it is easy to find jobs 
anywhere. I think my current salary is good, about NT $\$ 1,600$ per day, a little lower than Taiwanese colleagues, but higher than a factory salary. (Tram, 45, male)

Although I fear being caught by the police, I have more freedom to work outside. I can decide to do the jobs I like. You know, I often change phone numbers to prevent the police from tracking my phone. (Vui, 27, female)

The lack of legal status and the fear of being caught by the police, as well as debts, drive all the interviewees to send most of their earnings home, just keeping a little money for living expenses. Besides this, most of the interviewees revealed they have already paid off their debts and can start saving money. The following quotes show the ways in which Vietnamese migrants use their incomes:

I just leave a little money for living expenses, the rest I send home. I don't need to use much money here. I need to save money for my future. (Van, 23, female)

I paid off US $\$ 6,500$ of debt after six months of being a runaway. I leave about NT\$10,000 for leisure activities, because I smoke cigarettes and drink beers. I send home about NT\$22,000 to NT\$30,000 per month. (Binh, 25, male)

Finally, although always living in fear of being arrested and deported, most interviewees reveal they do not regret their time in Taiwan and regard runaway life as a gamble that depends on one's fortune; some feel that it has given them a chance to accumulate more money to invest back home, while others simply think that they must sacrifice themselves to help their families. However, sometimes, this sacrifice has to be paid with their lives. Phuong and Thien describe the following situation:

If a job was good, and its income was good enough, I would not run away. I don't want to see my mother's tears and my two brothers were out of work, so I decided to take this dangerous road. Many Vietnamese friends, while escaping from the police, have jumped from tall buildings and then died. I really don't understand why migrant workers have it so hard. (Phuong, 27, male) 
I know one day I may be arrested and deported by the police, so I try to work hard and earn money to support my children and my family, hoping that one day I can live a life like others do. (Thien, 35, male)

\section{Conclusion}

Discrimination, getting paid less than the minimum wage, a lack of respect, poor working/living environments, and heavy workloads tend to cause these foreign workers to become enraged with their employers in Taiwan. Research indicates that huge debts and guest-worker policies force Vietnamese migrant workers to run away. This research study also provides a detailed investigation of Vietnamese runaway workers and demonstrates how migrant networks are created and utilised among these workers in Taiwan. However, although migrant social networks play an important role in the runaway existence of Vietnamese workers in terms of finding jobs and support during periods of being a runaway, this is based almost entirely upon careful evaluation of trust. Economic duties to support their families impact the everyday lives of migrants. Besides this, there is a complex balance between solidarity, rivalry, trust and competition among groups of Vietnamese.

By investigating the social relationships between the different key players involved in the runaway existence of Vietnamese workers, particularly the relationship between runaway Vietnamese workers and illegal Taiwanese employers, this research study found a reciprocal relationship: runaway Vietnamese workers need jobs while their illegal Taiwanese employers need workers. They both depend on each other. Furthermore, research indicates that some Taiwanese landlords or Taiwanese workers do not pay a lot of attention to runaway foreign workers unless their rights and interests are violated by these runaway foreign workers. Finally, this research study also indicates the impact of their illegal status on their social activities, which lead most of them to work in the hidden economy.

\section{Acknowledgements}

I am grateful to the Professors in the Department of Southeast Asian Studies of National Chi Nan University for their helpful comments on a previous draft of this research study. I would like to thank all the Vietnamese migrant workers who gave so generously of their time to share the stories of their lives with me. 


\section{References}

Bloch, A. (2010). The right to rights? Undocumented migrants from Zimbabwe living in South Africa. Sociology, 44(2), 233-250.

Bourdieu, P., \& Wacquant, L. P. D. (1992). An invitation to reflexive sociology. Chicago, Illinois: University of Chicago Press.

Boyd, M. (1989). Family and personal networks in international migration: Recent developments and new agendas. International Migration Review, 23, 638-670.

Castles, S., \& Miller, M. J. (2009). The age of migration: International population movements in the modern world. New York, NY: Guilford Press.

Chang, G. (2000). Disposable domestics: Immigrant women workers in the global economy. Cambridge, MA: South End Press.

Chiou, M. L. (2008). Taiwan waiji laogong taoyi wenti zhi yanjiu [Study of runaway foreign labourers in Taiwan]. Master's thesis, Department of International Business, Hsuan Chuang University, Hsinchu, Taiwan.

Choldin, H. M. (1973). Kinship networks in the migration process. International Migration Review, 7, 163-176.

Chung, J. (2017, 15 December). Migrant workers believed killed in fire. Taipei Times. Retrieved from http://www.taipeitimes.com

Department of Immigration in Taiwan. (2015). The statistics of runaway migrant workers. $\quad 15$ Detrieved December 2017, from https://www.immigration.gov.tw

Elrick, T., \& Lewandowska, E. (2008). Matching and making labour demand and supply: Agents in Polish migrant networks of domestic elderly care in Germany and Italy. Journal of Ethnic and Migration Studies, 34(5), 717-734.

Hoang, L. A. (2015). Vietnamese migrant networks in Taiwan: The curse and boon of social capital. Ethnic and Racial Studies, 39(4), 690-707.

Hoang, L. A. (2016). Governmentality in Asian migrant regimes: The case of labour migration from Vietnam to Taiwan. Population, Space and Place, 23(3).

Hugo, G. (1995). International labor migration and the family: Some observations from Indonesia. Asian and Pacific Migration Journal, 4(2-3), 273-301.

Kohli, R. (2006). The sound of silence: Listening to what unaccompanied children say and do not say. British Journal of Social Work, 36, 707-721.

Lan, P. C. (2006). Global Cinderellas: Migrant domestics and newly rich employers in Taiwan. Durham, NC: Duke University Press.

Lin, B. H. (2004). Xianjieduan woguo wailao taoyi zhuangkuang qi wenti zhi yanjiu [Research on the present status and problems of run-away foreign 
workers in Taiwan]. Master's thesis, Department of Foreign Affairs Policy, Central Police University, Taoyuan, Taiwan.

Lin, H. F. (2007). Zai tai yuenan nuxing waiji laogong taoyi chenyin yu chaji zhi yanjiu [Research on fleeing and the arrest of Vietnamese female workers in Taiwan]. Master's thesis. Department of Criminal Investigation, Central Police University, Taoyuan, Taiwan.

Massey, D. (1988). Economic development and international migration in comparative perspective. Population and Development Review, 14(3), 383413.

Massey, D., Alarcón, R., Durand, J., \& González, H. (1987). Return to Aztlan: The social process of international migration from western Mexico. Berkeley: University of California Press.

Ministry of Labour. (2016). Foreign workers in Productive Industries and Social Welfare by Nationality. Retrieved 22 July 2016, from https://www.molgov.tw .Moore, G. (1990). Structural determinants of men's and women's personal networks. American Sociological Review, 55(5), 726-735.

Pham, D. N. (2005). Confucianism and the conception of the law in Vietnam. In J. Gillespie \& P. Nicholson (Eds.), Asian socialism and legal change: The dynamics of Vietnamese and Chinese reform (pp. 76-90). Canberra: ANU Press.

Portes, A. (Ed.). (1995). The Economic Sociology of Immigration. New York: Russell Sage Foundation.

Putnam, R. D. (1995). Bowling alone: America's declining social capital. Journal of Democracy, 6(1), 65-78.

Putnam, R. D. (2007). E pluribus unum: Diversity and community in the twentyfirst century, the 2006 Johan Skytte prize lecture. Scandinavian Political Studies, 30(2), 137-74.

Rodriguez, R. M. (2010). Migrants for export: How the Philippine state brokers labor to the world. Minneapolis, MN: University of Minnesota Press.

Ryan, L., Sales, R., Tilki, M., \& Siara, B. (2008). Social networks, social support and social capital: The experiences of recent Polish migrants in London. Sociology, 42(4), 672-690.

Sarker, R. (2016). Migration and employment: A study of Bangladeshi male migrant workers in Malaysia. In K. Lian, M. Rahman, \& Y. Alas (Eds.), International migration in Southeast Asia: Asia in transition (pp. 125-148). Singapore: Singapore.

Sheu, W. Y. (2000). Woguo feifa wailao guanzhi zhengce zhi yanjiu: zhengce zhixing lilun zhi guandian [The study of illegal foreigner worker regulative 
policies in the R.O.C. - From a policy implementation theory perspective]. Master's thesis, Department of Public Administration, National Chengchi University, Taipei, Taiwan.

Sui, C. (2017, 17 September). Did Taiwan police and paramedics leave migrant worker to die? $B B C$ News. Retrieved from http://www.bbc.com/news/world-asia.

Wang, H., \& Bélanger, D. (2007). Yigong, kuaguo zhongie yu zhidu sheji: shui cong tai yue guoji laodongli liudong huoli? [Transnational labor migration system between Vietnam and Taiwan: In whose interests?]. Taiwan: A Radical Quarterly in Social Studies, 65, 35-66.

Wang, H., \& Bélanger, D. (2011). Exploitative recruitment processes and working conditions of Vietnamese migrant workers in Taiwan. In A. Chan (Ed.), Labour in Vietnam (pp. 309-334). Singapore: ISEAS-Yusof Ishak Institute.

Wang, S. C. (2004). Woguo waiji laodong xuke ji guanli fazhi yu shijian zhi yanjiu [Research on the legal system and practice of permission and management for foreign workers in Taiwan]. Master's thesis, Institute of the Law of the Sea, National Taiwan Ocean University, Keelung, Taiwan.

Williams, L. (2006). Social networks of refugees in the United Kingdom: Tradition, tactics and new community spaces. Journal of Ethnic and Migration Studies, 32(5), 865-879.

$\mathrm{Wu}, \mathrm{C}$. Y. (2007). Shei liaokao zhu le yigong? Yuenan yigong zai tai de laodong zhuangkuang [Bonded Vietnamese guest workers in Taiwan]. Master's thesis, Graduate Institute of Southeast Asian Studies, National Chi Nan University, Nantou, Taiwan.

Wu, H. L. (2000, 21-22 March). Waiji laogong zai Taiwan de qushi yu wailao zhengce [Foreign workers' trends and foreign labour policy in Taiwan]. Paper presented at the Population, Family and Migrant Issues in the $21^{\text {st }}$ Century Seminar. Central for Population and Gender Studies, National Taiwan University, Taipei City, Taiwan.

\section{List of Informants}

\begin{tabular}{llll}
\hline Name & Gender & Age & Marital Status \\
\hline Binh & Male & 25 & Single \\
Cong & Male & 35 & Married \\
Dung & Male & 21 & Single \\
Hoa & Female & 24 & Single \\
Hung & Male & 27 & Single \\
\hline
\end{tabular}




\begin{tabular}{llll}
\hline Kiet & Male & 29 & Single \\
Mai & Female & 25 & Single \\
Nam & Male & 41 & Married \\
Phuong & Male & 27 & Single \\
Suong & Female & 25 & Single \\
Tai & Male & 37 & Married \\
Tham & Female & 30 & Single \\
Thanh & Male & 30 & Single \\
Thien & Male & 35 & Single \\
Tra & Female & 20 & Single \\
Tram & Male & 45 & Married \\
Trung & Male & 35 & Married \\
Tuan & Male & 26 & Single \\
Van & Female & 23 & Single \\
Vui & Female & 27 & Single \\
Xuan & Female & 25 & Single \\
\hline
\end{tabular}

Date Received: 26 May 2019

Date of Acceptance: 15 June 2019 